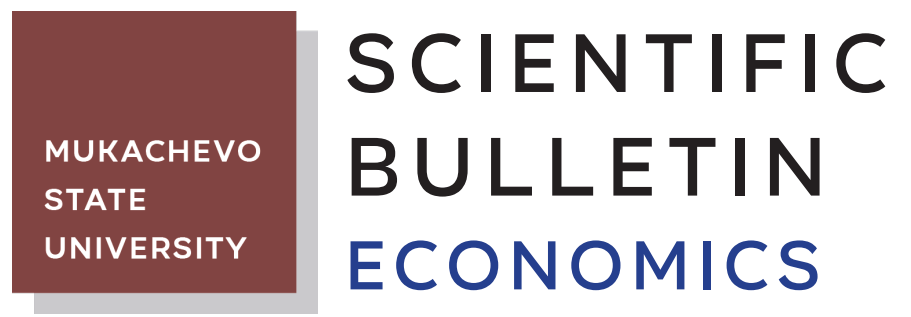

Volume 8, No. 2, 90-100

Journal homepage: https://economics-msu.com.ua/en

UDC 330.322

DOI: 10.52566/msu-econ.8(2).2021.90-100

\title{
Analysis of Organisational and Economic Support of Urban Parks in Ukraine
}

\author{
Nataliia V. Vernihorova* \\ Institute of Market Problems and Economic-Ecological Research the NAS of Ukraine \\ 65044, 29 Frantsuzkyi Blvd., Odesa, Ukraine
}

\begin{abstract}
The requirements of modern society for urban parks represent them as multifunctional territories. Global trends suggest that parks have a social essence and are focused on creating a healthy and aesthetic environment. But in Ukraine, parks are considered only as landscape and architectural complexes. Therefore, they are financed under urban planning programmes and at the expense of budget funds. Attracting funds from organisations in the field of landscaping requires greater integration of parks into the socio-economic system. At the same time, it is necessary to develop mechanisms for economic incentives for organisations to participate in the improvement of park areas. The purpose of this study is an economic analysis of modern financing of the green economy in Ukraine and the development of proposals for additional sources of financial support for parks. In this paper, using the analytical method, the accounting of the financial state of the green economy in the regions of Ukraine is carried out. Typical problems of modern financing, the main shortcomings of budget financing, and problems of commercial organisations in the field of urban greening are highlighted. Using the economic and mathematical modeling (index method), the analysis of changes in indicators of providing green spaces and, accordingly, indicators of their financial condition is carried out. The practical significance of the study lies in the development of recommendations on additional ways to finance park management based on the introduction of the practice of public-private partnerships, trust agreements, and easement. Requirements have been formed for legal entities that have the right to conclude such transactions. An economic mechanism for stimulating the establishment of publicprivate partnerships and concluding agreements in the field of landscaping is proposed
\end{abstract}

Keywords: park management, urban greening, natural capital, infrastructure support, landscaping, public space

Received: 22.02.2021, Revised: 19.05.2021, Accepted: 11.06.2021

Suggested Citation: Vernihorova, N.V. (2021). Analysis of organisational and economic support of urban parks in Ukraine. Scientific Bulletin of Mukachevo State University. Series "Economics”, 8(2), 90-100. 


\section{Introduction}

The key characteristic of the park among the variety of urban landscaping objects is its infrastructure support in accordance with public demand. The park, as a part of a public space, must be maintained. Providing parks with landscaping requires sufficient funding. Balanced landscaping requires the maintenance and improvement of green spaces and timely updating of infrastructure. In addition, as evidenced by foreign experience, the improvement of the park should meet the needs of society, which change over time, and therefore, there should be room for innovation. Thus, today the development of park management in Ukraine should be based on the best foreign practices.

The study of the development of parks and their promising opportunities is studied at an interdisciplinary level, in particular, as a socio-cultural phenomenon. The park is considered primarily as a leisure environment [1], and the scientific approach in the park management includes working with various categories of the population [2-3]. In world practice, parks are considered as natural capital, the concept of which is close to the natural resource potential. The following researchers studied the capitalisation of natural resource potential (capital): I.M. Bobukh [4], B.V. Burkinsky and V.F. Goryachuk [5], G.M. Shevchenko and M.M. Petrushenko [6].

Given that parks are an element of the public space of cities, their design and organisational and economic support should take into account the social component [7]. One of the most important organisations in the field of park research is the International Theme Park Service. The results of its research are systematically published in their specialised publications - "Amusement Business" and "Parks and recreation" [8]. Recent publications of which already analysed the impact of the COVID-19 pandemic on promising areas in the field of park construction [9], tips for safe use of parks during the pandemic [10].

Given the recent publications, it can be argued that the priority areas that are considered by scientists and service workers are: justice in the accessibility and use of park space $[11,12]$; the park as an indicator of social and economic well-being $[13,14]$; the use of abandoned and spent natural or urban areas to create parks, stimulating public-private partnership in the field of public space [15]; organisational and economic support of parks in accordance with the individual characteristics of territories and the needs of communities. The latter direction, for Ukraine, can be developed in accordance with the needs of territorial communities [16]. The National Parks and Recreation Association (USA) also develops scientific approaches to creating parks and conducts statistical research [17]. In other words, urban parks in the world experience have significant advantages over Ukrainian parks, primarily as socio-economic objects. Their integration into the life of the urban population, functionality as an element of public space, provides many opportunities for finding alternative ways of development, expanding sources of financing, and implementing the best park space projects.
Taking into account international practice, the purpose of the study is to develop proposals for additional ways to provide financial support for urban parks with the involvement of funds from legal entities. It is also necessary to provide economic mechanisms for stimulating extrabudgetary revenues. In accordance with this, the aim of the study is to investigate the current state of organisational and economic support for green economy in the regions of Ukraine, to analyse the leisure opportunities of parks in the world.

\section{Materials and Methods}

At the beginning of the study, the relationship between the natural and infrastructural components of the park space was illustrated using a graphical method. The graphic method allows briefly reflecting the interdependence of components and changes in quality characteristics depending on their ratio. The next method is economic analysis. Its special feature is the use of reporting materials in numerical form, the study of economic activity in a particular area, the interdependent impact and changes in indicators, and consistency in the study of an object. The main statistical base of the study were the reports of the Ministry of community and territory development of Ukraine on the state of the green economy during 2014-2019 [18-23], containing information mainly of an economic nature. The conclusions were drawn about the financial and infrastructure security of parks based on data on public green spaces. Therefore, the change in the indicator of maintenance of public plantings during 2014-2019 and their financial support were analysed.

At the first stage, using the method of economic analysis, the level of provision of general-purpose green spaces with landscaping is considered, which provides for the support of both the natural and infrastructure components. The dialectical approach of this method allows the study to assess the change in the indicator of landscaping provision in dynamics (during 2014-2019). At the second stage, also using the method of economic analysis, the relationship between the level of improvement of green spaces and the implementation of financial programmes is shown, comparing its decline with the uncollected expenses in 2017. At the third stage, the analysis of the financial support of public green spaces continued. Next, the study considers the accounting of expenses in the field of green economy by regions of Ukraine and determine which points of expenditure have the highest percentage value of expenses. As part of this stage, the index method is also used, which can be used to consider the overall dynamics of indicators of general-purpose green spaces and their financing. As a result, using the method of economic and mathematical modelling (index method), the general trend in the green economy of Ukraine (2015-2019) is analysed for the following indicators: damage by phytodiseases, changes in the area of public plantings, culture and recreation parks, water parks, expenses for the maintenance of plantings, accounts payable and receivables. 


\section{Results and Discussion}

Organisational and economic support of parks should take place from the standpoint of their role in the city system, namely: as a component of the public space of cities, and the value of their natural capital. The concept of "natural capital" is closely related to the concept of "natural resource potential". According to I.M. Bobukh, parks belong to the natural resource potential of renewable recreational resources. The natural capital implies "a set of natural resources that are owned by the economic units of a given country and are used for the purpose of creating added value and/or generating profit or other economic benefits" [4].

From the standpoint of added value, the park, as natural capital, should have a sufficient level of care and infrastructure support. Unlike forests, forest belts, sanitary protection zones and plantings grown by self-seeding, parks have an integral element - infrastructure support. The park is an important part of the public space of the city and according to SCR B. 2.2-12:2019 (clause 8.2.1), belongs to public areas: "the green spaces of public use of settlements include multifunctional and specialised parks, gardens, squares, boulevards, urban forest parks, green areas of embankments and beaches, botanical gardens and zoological parks, parks-monuments of landscape art and other natural and artificially created landscape objects" [24]. And according to Article 13 of the Law of Ukraine "On improvement of settlements" [25], the park, as a part of public space, is subject to mandatory improvement and maintenance of infrastructure. Thus, the sphere of improvement of urban green spaces is a separate branch of the national economy, and the park is one of the elements of public space and commercial interests. The lack of maintenance of infrastructure is bound to have negative consequences - environmental, social, and economic. Therefore, the presence of parks with developed infrastructure in the city increases the cost of adjacent housing by up to $40 \%$. The lack of landscaping and the presence of marginal elements in parks creates the opposite effect. Therefore, capitalisation at the expense of parks depends on the infrastructure component [26].

The key factor in the best manifestation of the qualities of ecosystem services of parks is a balanced combination of infrastructure support and maintenance of green spaces. The combination of the infrastructure component and the mass of green spaces that make up the park can be illustrated in the form of a balance curve (Fig. 1 ), which clearly shows the importance of the balance of green spaces and infrastructure support and changes in the species diversity of parks depending on their ratio. The park is a natural capital, but it must have infrastructure support and care.

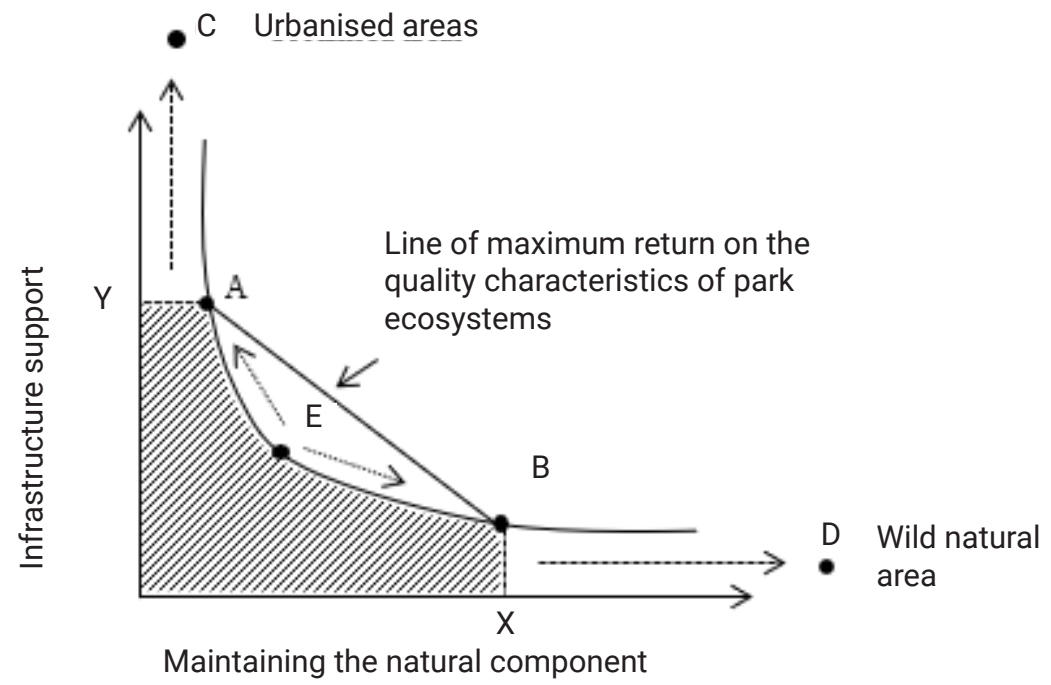

Figure 1. Schematic representation of the balance of natural and infrastructure component of parks Source: developed by the author

As can be seen from Figure 1, getting the greatest return on the park environment is possible with a balanced combination of green spaces and infrastructure. Excessive growth of plantings and lack of infrastructure (point D) reduces the possibility of using the park area by citizens. Excessively developed infrastructure (many food establishments, attractions, children's and sports grounds and entertainment complexes) on the territory of the park can disrupt the comfortable stay and recreational impact of the natural component. Such a park becomes more similar to the usual public places (point $\mathrm{C}$ ). The need for the ratio of the natural component and infrastructure support of a particular park follows from its type. Multifunctional parks that include culture and recreation parks are marked by point E. They are designed to meet the needs of the widest segments of the population and necessarily perform a recreational function. The segment on Curve A-B, marked with an arrow from $\mathrm{E}$ to $\mathrm{A}$, can be timed to coincide with specialised parks for which infrastructure plays a crucial role in their specialisation (sports, children's, health-improving, exhibition, ethnographic, water parks). The segment marked with an arrow from $\mathrm{E}$ to $\mathrm{B}$ indicates specialised 
parks of nature protection significance and tend to favour the natural component (forest parks, recreational forests, botanical gardens, national parks).

In the reporting on the state of the green economy sector, the Ministry of community and territory development of Ukraine [27], there are no data on the provision of park care. But there is information about public green spaces [1823]. Therefore, one of the prerequisites for the quality of ecosystem services of parks is to provide public green spaces with tendance (Table 1).

Table 1. Change in the indicator of provision of care for public green spaces by oblasts, 2014-2019 (\%)

\begin{tabular}{|c|c|c|c|c|c|c|}
\hline Oblasts & 2014 & 2015 & 2016 & 2017 & 2018 & 2019 \\
\hline 1 & 2 & 3 & 4 & 5 & 6 & 7 \\
\hline Vinnytska Oblast & 59 & 59 & 59 & 60 & 70 & 70.2 \\
\hline Volynska Oblast & $\underline{100}$ & $\underline{100}$ & $\underline{100}$ & $\underline{100}$ & $\underline{100}$ & $\underline{100}$ \\
\hline Dnipropetrovska Oblast & 71 & $\underline{100}$ & $\underline{100}$ & 79 & $\underline{81}$ & $\underline{80.7}$ \\
\hline Donetska Oblast & 50 & 49 & 49 & 48 & 48 & 48 \\
\hline Zhytomyrska Oblast & 62 & 62 & 62 & 62 & 62 & 62.2 \\
\hline Zakarpatska Oblast & 86 & 81 & $\underline{96}$ & 90 & $\underline{90}$ & $\underline{90}$ \\
\hline Zaporizka Oblast & 36 & 40 & 41.5 & 42 & 37 & 40.6 \\
\hline Ivano-Frankivska Oblast & 56 & 56 & 74 & 74 & 71 & 77.1 \\
\hline Kyivska Oblast & 64 & 64 & 64 & 64 & - & 63.6 \\
\hline Kirovohradska Oblast & 40 & 40 & 40.9 & 41 & 41 & 41.3 \\
\hline Luhanska Oblast & - & 79 & - & 77 & 74 & 77.7 \\
\hline Lvivska Oblast & $\underline{100}$ & $\underline{100}$ & $\underline{100}$ & $\underline{100}$ & $\underline{100}$ & $\underline{100}$ \\
\hline Mykolaivska Oblast & 100 & 100 & $\underline{100}$ & $\underline{100}$ & $\underline{100}$ & 100 \\
\hline Odeska Oblast & $\underline{100}$ & $\underline{100}$ & $\underline{100}$ & 71 & 75 & 50.1 \\
\hline Poltavska Oblast & $\underline{100}$ & $\underline{100}$ & $\underline{100}$ & $\underline{100}$ & $\underline{100}$ & $\underline{100}$ \\
\hline Rivnenska Oblast & $\underline{86}$ & $\underline{86}$ & $\underline{89.8}$ & $\underline{90}$ & $\underline{91}$ & $\underline{90}$ \\
\hline Sumska Oblast & 50 & 50 & 84 & 51 & 51 & 50.6 \\
\hline Ternopilska Oblast & $\underline{96}$ & $\underline{96}$ & $\underline{100}$ & $\underline{100}$ & $\underline{100}$ & $\underline{100}$ \\
\hline Kharkivska Oblast & 81 & 81 & 81 & $\underline{81}$ & $\underline{81}$ & $\underline{100}$ \\
\hline Khersonska Oblast & 72 & 72 & 86 & 90 & $\underline{100}$ & 77.7 \\
\hline Khmelnytska Oblast & $\underline{100}$ & $\underline{100}$ & $\underline{100}$ & 85 & $\underline{100}$ & $\underline{100}$ \\
\hline Cherkaska Oblast & 51 & 51 & 51 & 53 & 54 & 54.7 \\
\hline Chernivetska Oblast & $\underline{100}$ & $\underline{100}$ & 100 & 100 & $\underline{100}$ & 100 \\
\hline Chernihivska Oblast & $\underline{100}$ & $\underline{100}$ & $\underline{100}$ & 11 & 11 & 11.3 \\
\hline Kyiv city & $\underline{100}$ & $\underline{100}$ & $\underline{100}$ & $\underline{100}$ & $\underline{100}$ & $\underline{100}$ \\
\hline Total in Ukraine & 69 & 77.3 & 78.8 & 65 & 65 & 65.5 \\
\hline
\end{tabular}

Note: numbers in bold italics indicate the lowest annual values for the maintenance of general-purpose green spaces, and underlined Italics indicate the highest

Source: compiled by the author based on [18-23]

Thus, the highest rates of providing care for generalpurpose green spaces during 2014-2019 were observed in the following oblasts: Volynska, Lvivska, Mykolaivska, Poltavska, Ternopilska, Chernivetska, and Kyivska - 100\% provision. Relatively high rates in were observed in the Rivnenska and Kharkivska Oblasts. Zaporizka and Kirovohradska Oblasts had the lowest annual indicators of maintenance of green spaces - within $40 \%$. A steady trend towards a decrease in the maintenance of green spaces is observed in two oblasts - Odeska and Chernihivska. The Odeska Oblast during 2014-2016 had 100\% provision of green spaces with care, since 2017 there has been a decrease to $50.1 \%$ (as of 2019). In Chernihivska Oblast, it was the same - 100\% during 2014-2016, and since 2017 - a sharp drop to $11 \%$.

Next, the study considers the problem of providing care for general-purpose green spaces in the Chernihivska Oblast in more detail. According to the report on the "programme for the development and preservation of green spaces in settlements of the Chernihivska Oblast for 20132017" [28] based on data from 2017, financing of measures to create and support green spaces was carried out at the expense of three main sources. Thus, according to the report, in 2017 it was planned to allocate $26,400.14$ thousand UAH, 
in particular at the expense of:

- state budget - 2,000.0 thousand UAH (not allocated);

- budgets of local government bodies - 14,901.1 thousand UAH;

- other sources of financing - 9,499.04 thousand UAH. In the end, the amount of expenses incurred amounted to $14,964.3$ thousand UAH, instead of the planned $26,400.14$ thousand UAH. The deviation from the funding provided for the programme was 11,435.8 thousand UAH. In other words, the planned expenses from the state budget were not fulfilled at all. As can be seen from Table 1, starting in 2017, the level of provision of green spaces with care in the Chernihivska Oblast fell to $11 \%$. It can be assumed that the main share of funding was from the local budget and partially from other sources. This practice is the most common. Therefore, when drawing up programmes for creating and supporting public green spaces, it is necessary to provide reliable sources of funding and look for interested partners.

Urban planning and green economy development programmes should include opportunities for cooperation with commercial organisations to create green spaces. The presence of a large number of subjects of green landscaping creates healthy competition, which means it contributes to the best park projects. But such cooperation should include the interests of organisations. The principle of residual financing of green spaces is inappropriate in this case. Therefore, the results of reviews from representatives of commercial urban landscaping organisations, in particular, TOPIAR (Kyiv, 2019) were analysed [26]. It can be stated that the main problems of landscaping companies in modern cities of Ukraine are:

- the lack of long-term programmes and plans for the development of green areas for 10-20 years;

- the lack of a legal framework for extending and protecting contracts of landscaping companies with the city government when it changes. That is, all contracts from the previous cadence of the mayor are being terminated. At the same time, the establishment of parks goes through certain stages that exceed the period of 5-6 years;

- inefficient management of the park economy: inefficient use of funds, violation of agrotechnical standards during works;

- the lack of possibility of subscription and long-term contracts within the limits of budget financing;

- the city authorities choose companies that provide the cheapest services;

- the absence of an independent expert committee that would assess the company's work on landscaping, as well as the officials responsible for the project;

- lack of dialogue between the authorities and society regarding the work performed and its quality.

Notably, the above comments of the representative of a commercial greening organisation coincide with the positions of the World Health Organisation (WHO) on the development of green areas. Thus, the WHO report notes the approach of long-term prospects in the planning of Parks and other landscaping facilities, including [29]:

- green urban space requires long-term development and maintenance;

- the advantages of green areas manifest themselves over time - with the growth of plantings and development of ecosystems;

- planning of green areas should be flexible, that is, provide for the possibility of changes in accordance with the demand of society.

In addition, WHO considers the creation of green zones in cities as investments in the community needs (green zones as an important element of public space), and in health (creating conditions for physical and mental wellbeing). Nowadays, the state of financial support does not allow to provide sufficient care for general-purpose green spaces (Table 2).

Table 2. Cost record of maintaining general-purpose green spaces in 2019 by oblasts

\begin{tabular}{|c|c|c|c|c|c|c|}
\hline \multirow[b]{2}{*}{ Administrative division } & \multicolumn{6}{|c|}{ Expenses for the maintenance of public green spaces, ths. UAH } \\
\hline & Total & $\begin{array}{l}\text { Material } \\
\text { costs, (\%) }\end{array}$ & $\begin{array}{l}\text { Labour } \\
\text { costs, (\%) }\end{array}$ & $\begin{array}{l}\text { Deductions } \\
\text { for social } \\
\text { events, }(\%)\end{array}$ & $\begin{array}{c}\text { Depreciation, } \\
(\%)\end{array}$ & $\begin{array}{c}\text { Other } \\
\text { operating } \\
\text { expenses, (\%) }\end{array}$ \\
\hline 1 & 2 & 3 & 4 & 5 & 6 & 7 \\
\hline Vinnytska Oblast & 32431.378 & $35 \%$ & $42 \%$ & $8 \%$ & $3 \%$ & $11 \%$ \\
\hline Volynska Oblast & 5744.6 & $28 \%$ & $47 \%$ & $10 \%$ & $1 \%$ & $14 \%$ \\
\hline Dnipropetrovska Oblast & 129771.37 & $14 \%$ & $27 \%$ & $8 \%$ & $3 \%$ & $48 \%$ \\
\hline Donetska Oblast & 157782.524 & $16 \%$ & $52 \%$ & $11 \%$ & $1 \%$ & $19 \%$ \\
\hline Zhytomyrska Oblast & 21974.8 & $27 \%$ & $51 \%$ & $13 \%$ & $3 \%$ & $6 \%$ \\
\hline Zakarpatska Oblast & 28888.4 & $55 \%$ & $26 \%$ & $17 \%$ & $1 \%$ & $1 \%$ \\
\hline Zaporizka Oblast & 92410.55 & $22 \%$ & $53 \%$ & $11 \%$ & $4 \%$ & $9 \%$ \\
\hline Ivano-Frankivska Oblast & 26559 & $25 \%$ & $53 \%$ & $11 \%$ & $2 \%$ & $9 \%$ \\
\hline Kyivska Oblast & 14530.32 & $18 \%$ & $46 \%$ & $21 \%$ & $8 \%$ & $8 \%$ \\
\hline
\end{tabular}


Table 2, Continued

Expenses for the maintenance of public green spaces, ths. UAH

\begin{tabular}{|c|c|c|c|c|c|c|}
\hline \multirow[b]{2}{*}{ Administrative division } & \multirow[b]{2}{*}{ Total } & \multicolumn{5}{|c|}{ In particular: } \\
\hline & & $\begin{array}{c}\text { Material } \\
\text { costs, (\%) }\end{array}$ & $\begin{array}{l}\text { Labour } \\
\text { costs, (\%) }\end{array}$ & $\begin{array}{l}\text { Deductions } \\
\text { for social } \\
\text { events, (\%) }\end{array}$ & $\begin{array}{l}\text { Depreciation, } \\
(\%)\end{array}$ & $\begin{array}{l}\text { Other operating } \\
\text { expenses, }(\%)\end{array}$ \\
\hline Kirovohradska Oblast & 34939.4 & $37 \%$ & $45 \%$ & $9 \%$ & $2 \%$ & $7 \%$ \\
\hline Luhanska Oblast & 8445.1 & $39 \%$ & $38 \%$ & $8 \%$ & $2 \%$ & $13 \%$ \\
\hline Lvivska Oblast & 52141.5 & $16 \%$ & $42 \%$ & $12 \%$ & $4 \%$ & $26 \%$ \\
\hline Mykolaivska Oblast & 32321.95 & $23 \%$ & $51 \%$ & $17 \%$ & $1 \%$ & $7 \%$ \\
\hline Odeska Oblast & 74965.8 & $9 \%$ & $74 \%$ & $15 \%$ & $0 \%$ & $2 \%$ \\
\hline Poltavska Oblast & 25564 & $20 \%$ & $50 \%$ & $11 \%$ & $3 \%$ & $15 \%$ \\
\hline Rivnenska Oblast & 30077.68 & $17 \%$ & $58 \%$ & $12 \%$ & $7 \%$ & $7 \%$ \\
\hline Sumska Oblast & 28843.2 & $49 \%$ & $14 \%$ & $12 \%$ & $17 \%$ & $8 \%$ \\
\hline Ternopilska Oblast & 7521.922 & $33 \%$ & $52 \%$ & $5 \%$ & $3 \%$ & $6 \%$ \\
\hline Kharkivska Oblast & 223701.63 & $26 \%$ & $36 \%$ & $8 \%$ & $8 \%$ & $22 \%$ \\
\hline Khersonska Oblast & 26100 & $41 \%$ & $46 \%$ & $7 \%$ & $0 \%$ & $5 \%$ \\
\hline Khmelnytska Oblast & 37101.74 & $19 \%$ & $57 \%$ & $13 \%$ & $7 \%$ & $4 \%$ \\
\hline Cherkaska Oblast & 23866.5 & $54 \%$ & $32 \%$ & $7 \%$ & $0 \%$ & $7 \%$ \\
\hline Chernivetska Oblast & 9948.4 & $30 \%$ & $55 \%$ & $14 \%$ & $0 \%$ & $0 \%$ \\
\hline Chernihivska Oblast & 22786.1 & $26 \%$ & $39 \%$ & $7 \%$ & $3 \%$ & $25 \%$ \\
\hline Kyiv city & 0 & 0 & 0 & 0 & 0 & 0 \\
\hline Total in Ukraine & 1148417.864 & $24 \%$ & $44 \%$ & $10 \%$ & $4 \%$ & $18 \%$ \\
\hline
\end{tabular}

Source: compiled by the author based on [18-23]

As can be seen from Table 2, as of 2019, most of the costs of maintaining green spaces, except for the Dnipropetrovska, Zakarpatska, Luhanska, Sumska, and Cherkaska Oblasts, go to labour remuneration. In second place material costs, that is, directly infrastructure support and measures to support green spaces. Only in Kyivska and Odeskaa Oblasts, spending on material support is in third place - after social events. Moreover, in the Odeska Oblast, the situation with the distribution of financial security is the worst. Labour costs account for $74 \%$ of the total funding for the maintenance of green spaces, followed by deductions for social events $-15 \%$, and material support - only $9 \%$.

For the development of any economic entity, the availability of loan capital is important. It includes depreciation charges, monetary savings of the population, and temporarily available state funds. As for depreciation costs, they are so low in the Odeska, Khersonska, Cherkaska, and Chernivetska Oblasts, that they do not have a percentage value $(0 \%)$. This means that when the time comes for the renewal of fixed assets, the funds will be absent. A high percentage of depreciation costs in relation to other items of expenditure is observed in the Sumska Oblast (17\%).

Next, the study looks at the general trend in Ukraine in the green economy during 2015-2019. To analyse changes and compare various indicators of green space provision, the method of economic and mathematical modelling was used, namely, the index method. The results are presented in Table 3.

Table 3. Analysis of changes in indicators of green space provision using the index method (2015-2019)

\begin{tabular}{ccccccccccc} 
Years & $\begin{array}{c}\text { Total area } \\
\text { of plantings } \\
\text { (ths. ha.) }\end{array}$ & I 1 & $\begin{array}{c}\text { Plantings } \\
\text { affected by } \\
\text { phytodiseases } \\
\text { (ths. } \mathbf{m}^{2} \text { ) }\end{array}$ & I 2 & $\begin{array}{c}\text { Public } \\
\text { plantings } \\
\text { (ths. ha.) }\end{array}$ & I 3 & $\begin{array}{c}\text { Culture and } \\
\text { recreation } \\
\text { parks } \\
\text { (ths. ha.) }\end{array}$ & $\begin{array}{c}\text { I 4 } \\
\text { Water parks, } \\
\text { forest parks, } \\
\text { meadow } \\
\text { parks } \\
\text { (thsd. ha.) }\end{array}$ & I 5 \\
\hline 2015 & 457 & 0,872 & 219 & 0,512 & 117 & 0.96 & 15 & 0,937 & 19 & 0.95 \\
\hline 2016 & 443 & 0.97 & 215 & 0,982 & 117 & 1 & 14.3 & 0,953 & 19.1 & 1,005 \\
\hline 2017 & 494 & 1,115 & 197.5 & 0,919 & 138.7 & 1,185 & 17 & 1,189 & 29.8 & 1,497 \\
\hline 2018 & 479.3 & 0.97 & 3,833 & 0.02 & 134 & 0,966 & 18.1 & 1,065 & 29.9 & 1.003 \\
\hline
\end{tabular}


Table 3, Continued

\begin{tabular}{|c|c|c|c|c|c|c|c|c|c|c|}
\hline Years & $\begin{array}{c}\text { Total area } \\
\text { of plantings } \\
\text { (ths. ha.) }\end{array}$ & I 1 & $\begin{array}{l}\text { Plantings } \\
\text { affected by } \\
\text { phytodiseases } \\
\left.\text { (ths. } \mathbf{m}^{2}\right)\end{array}$ & I 2 & $\begin{array}{l}\text { Public } \\
\text { plantings } \\
\text { (ths. ha.) }\end{array}$ & I 3 & $\begin{array}{l}\text { Culture and } \\
\text { recreation } \\
\text { parks } \\
\text { (ths. ha.) }\end{array}$ & I 4 & $\begin{array}{l}\text { Water parks, } \\
\text { forest parks, } \\
\text { meadow } \\
\text { parks } \\
\text { (thsd. ha.) }\end{array}$ & I 5 \\
\hline 2019 & 403.4 & 0,842 & 501.2 & 130,759 & 135.7 & 1.017 & 18.2 & 1,006 & 29.9 & 1 \\
\hline $\begin{array}{l}\text { Averag } \\
\text { the ind }\end{array}$ & $\begin{array}{l}\text { change in } \\
x \text { (average I) }\end{array}$ & 0.95 & & 1.04 & & 1.12 & & 1.03 & & 1.07 \\
\hline
\end{tabular}

\section{Notes:}

I 1 - annual indices of changes in total green space areas for 2015-2019;

I 2 - annual indices of changes in plantings affected by phytodiseases for 2015-2019;

I 3 - annual indices of changes in the area of public green spaces for 2015-2019;

I 4 - annual indices of changes in the area of culture and recreation parks for 2015-2019;

I 5 - annual indices of changes in the area of water parks, forest parks, and meadow parks for 2015-2019

Source: compiled by the author based on [18-23]

As can be seen from Table 3, over the past five years, there has been a slight tendency to increase the area of public green spaces, in particular, culture and recreation parks, water parks, forest parks, and meadow parks. At the same time, there is a slight decrease in the total area of green spaces. Of particular note is the increase in the index of phytodiseases, which increased significantly in 2019.

In the field of landscaping, the main areas of financing should be the maintenance of green spaces and infrastructure equipment of public landscaping areas. As can be seen from Table 2, in the oblasts of Ukraine, the structure of expenses in the field of landscaping is very different. Not always the main share of funding goes to the maintenance of green spaces. Nevertheless, changes in financial support primarily affect the quality of landscaping and infrastructure support. Therefore, the obtained indices of green space provision with the indices of changes in their financial provision will be compared (Table 4).

Table 4. Analysis of changes in indicators of financial support for public green spaces using the index method (2015-2019)

\begin{tabular}{|c|c|c|c|c|c|c|}
\hline Years & $\begin{array}{c}\text { Expenses for the } \\
\text { maintenance of public } \\
\text { green spaces (mln. UAH) }\end{array}$ & 16 & $\begin{array}{c}\text { Accounts payable } \\
\text { of landscaping } \\
\text { companies (mln. UAH) }\end{array}$ & 17 & $\begin{array}{c}\text { Accounts receivable } \\
\text { of enterprises } \\
\text { (mln. UAH) }\end{array}$ & 18 \\
\hline 2015 & 395 & 1,088 & 22.4 & 0.54 & 12.8 & 0.3 \\
\hline 2016 & 536 & 1,357 & 33.2 & 1.48 & 14.2 & 1,109 \\
\hline 2017 & 995 & 1,856 & 29.2 & 0.88 & 22.9 & 1.61 \\
\hline 2018 & 934 & 0.94 & 63.7 & 2.18 & 29.7 & 1,297 \\
\hline 2019 & 1148.4 & 1.23 & 74.3 & 1,166 & 36.9 & 1,242 \\
\hline \multicolumn{2}{|c|}{$\begin{array}{c}\text { Average change in the index } \\
\text { (av-erage I) }\end{array}$} & 1.26 & & 1.12 & & 0.97 \\
\hline
\end{tabular}

\section{Notes:}

I 6 - annual indices of changes in the cost of maintaining public green spaces for 2015-2019;

I 7 - annual indices of changes in accounts payable of enterprises for the maintenance of green spaces for 2015-2019; I 8 - annual indices of changes in accounts receivable of enterprises for the maintenance of green spaces for 2015-2019; Source: compiled by the author based on [18-23]

Table 4 shows that for the period 2015-2019, the following trends were observed in the maintenance of public green spaces: an increase in the cost of maintaining green spaces, an increase in accounts payable and receivables. The lack of funding in this area hinders the disclosure of the environmental and economic potential of ecosystem services in parks. Therefore, it is relevant to introduce alternative ways of financial support for parks and its incentives. Notably, improvement of financial security is closely related to the overall investment policy of the state [30]. Modern parks in the world function and develop as multifunctional institutions. Their cost-effectiveness is determined by the number of visits. Therefore, the development of parks is aimed at creating comfortable conditions and meeting the needs of the majority of the population [31]. Given this fact, the study offers to raise funds from legal entities, for example, by entering into agreements of an environmental trust and a land or nature reserve easement with interested parties.

The use of a conservation trust is attractive for both park development and land owners. Funds under the environmental trust are directed to measures to protect the ecosystem, and owners are required to abandon construction and other unfavourable activities. Such an agreement allows the land owner to receive tax benefits. Financing 
through protected easements - allows attracting investors to preserve valuable nature parks, and investors, for their part, get a preferential discount. It is estimated that conservation partnerships under the reserve easement during 2005-2015 increased land conservation by $175 \%$ [32].

At the same time, it is important to maintain state control of park territories. Therefore, the organisation of extra-budgetary financing of parks with the possibility of commercial activities can be organised within the framework of a public-private partnership. Today, such partnerships in the field of environmental protection are common in the United States and Canada, in the housing and communal services sector - in Italy. In Ukraine, a common form of public-private partnership is a concession, but cases of concluding such an agreement in the field of landscaping are unknown [33]. However, there are already studies on the introduction of public-private partnership in the field of land management and land use in Ukraine [34].

In this context, it is important to choose interested parties for making an agreement. The global trends show that at the end of the 20th century, parks turned into social and educational complexes. Therefore, it would be logical to support this direction for parks in Ukraine, because trends in the organisation of public space are determined by the demand of society. Therefore, when concluding land easements and trusts, concluding public-private partnerships, it is advisable to identify the range of possible applicants for these transactions. From the standpoint of meeting social and educational needs, these can be: cultural and educational institutions, upbringing, sports and creative clubs, medical institutions. The idea is to use a share of the park area for educational, cultural, and rehabilitation activities. In this case, social programmes are carried out not only within the premises of the relevant organisations, but can also be conducted in a natural environment in the fresh air. For example, the opportunity to play sports professionally in a specially equipped summer pavilion will be an attractive opportunity to spend time in the fresh air. This is a good opportunity both to attract visitors to the relevant institutions, and to encourage the creation of parks in different parts of the city by increasing their economic efficiency. The expansion of the city's park network through the creation of regional parks is particularly relevant in the context of forecasts of foreign scientists. In the future, mixed-type multifunctional parks will become popular, which will have [31]:

- walking area;

- thematic zoning;

- commercial recreational opportunities;

- implementation of creative leisure activities.

The best foreign practices show how different categories of parks can be adapted to different social and educational programmes (Table 5):

Table 5. Possibilities for organising leisure parks of various categories in the world

\section{Category and its features}

State parks. National, ethnographic, landscape, state reserves, sea coasts, national recreation areas, nature conservation areas, reservoirs, forests, cultural monuments, memorials

Parks in states, counties, and municipalities.

Parks that serve the population of a particular They have cultural and tourist programmes financed from city budgets state or county

Urban parks. The purpose of creating parks is Educational programmes in children's parks, their zoning and to improve a person's leisure time, ecological equipment in accordance with the age categories of children. culture, and develop aesthetic qualities. The Cooperation with rehabilitation centres and nursing homes. The combination of landscape design and nature following programmes are known: "Recreation in the park for the protection is important

\section{Source: compiled based on [31]}

In short, the foreign park construction industry pays attention to the social essence of parks and the organisation of a healthy and aesthetic environment. But in Ukraine, parks are considered as architectural complexes in the urban space planning. When identifying legal entities that have an advantage in entering into an easement or trust agreement, the following requirements can be formed:

- territorial affiliation to the perimeter of the park area;

- availability of a prescribed activity plan that does not contradict the standards of activity on the territory of parks;

- financial statements confirming the organisation's

\section{Social and educational programmes}

They have areas for camps, museums, exhibition halls on their rritory;

Separate educational programmes for children: "Junior-ranger" in the USA, "Ocean News", "Wildlife", "Ecology of Alaska", "Economy and Environment", "Friends of the Little Prince of Earth". Environmental elderly", "Golden Age", "New Horizons"

ability to maintain a section of the park in proper condition;

- their activities do not contradict the conditions of a relaxing holiday in the park, do not lead to crowds, do not cause damage to green spaces and lawns, and do not lead to building-up of the territory.

Admittedly, the organisation should benefit from measures to care for and maintain the park's territory. Therefore, appropriate incentives can be offered to create public-private partnerships in parks, and conclude easement and trust agreements (Fig. 2): 


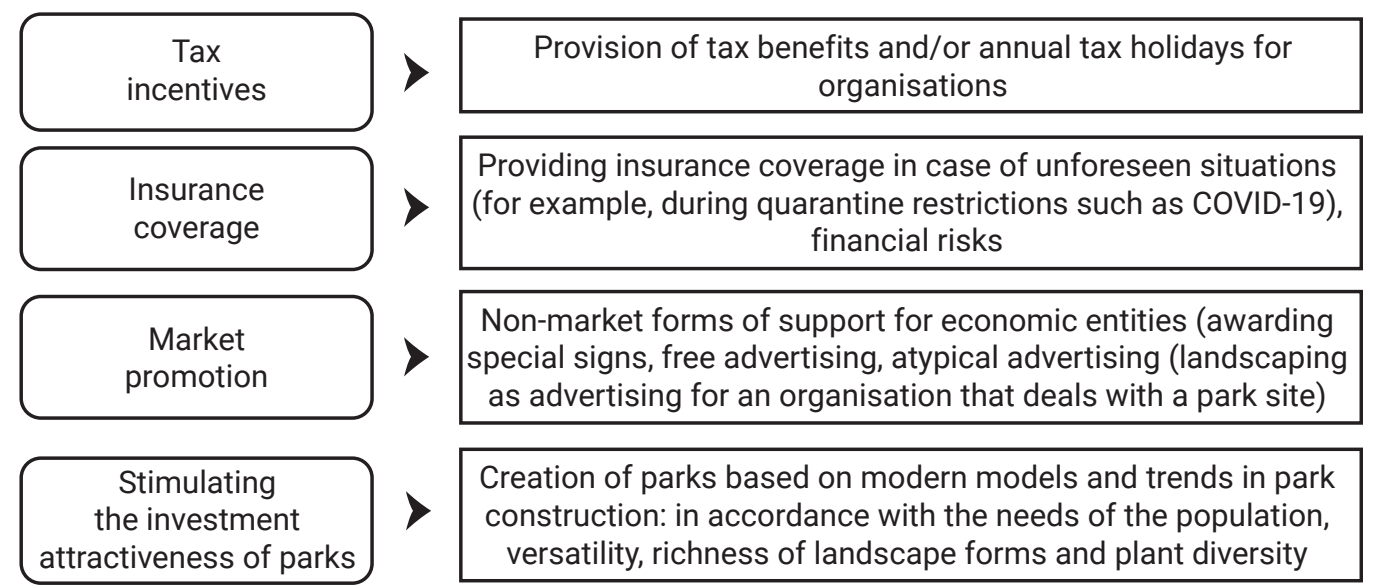

Figure 2. Economic mechanisms for stimulating the establishment of public-private partnerships and the conclusion of land easement and trust agreements in the field of landscaping

Source: compiled by the author

Taking into account the above, it can be stated that the organisation of a modern urban park requires the work of specialists in urban space planning, educational and recreational spheres. Unlike wild natural areas, the park has social and economic significance in the urban environment, while maintaining its environmental significance. Therefore, the creation of the State Parks Agency of Ukraine is proposed, which could organise and control extra-budgetary financing of parks of all categories, establish relations with relevant international organisations, and conduct socially oriented research in the field of park management. Within the framework of the agency's activities, it is possible to organise independent expert commissions to assess the quality of landscaping works under the city authorities. Similar structures already operate in many countries: the National Parks and Recreation Association (USA), The National Recreation and Tourism Foundation (USA), the Institute of Leisure and Entertainment Management (Great Britain), the Association of Municipal Parks and Gardens Managers (Netherlands), the Parks and Recreation Foundation (Japan), and others [31].

International organisations specialising in park development include: EUROPARC Federation (although specialising in parks of protected status) [35], the International Theme Park Service, and the International Association of Amusement Parks and Attractions. These organisations are open to cooperation and have best practices in the field of park leisure [36].

\section{Conclusions}

It can be stated that public plantings include: culture and recreation parks, city and district parks, gardens of residential areas attached to residential buildings, squares, embankments and boulevards, water parks, meadow parks, forest parks, and other landscaping objects. Therefore, the study considers a high level of provision of public green spaces with care as one of the prerequisites for the quality of ecosystem services. Analysis of the financial condition of the green economy in Ukraine and the state of its improvement has indicated that today in Ukraine there are no services that report on organisational and economic support specifically for parks. The current level of funding and organisational support often does not meet the needs of society. The problem lies in the following:

- impractical redistribution of funds, even with one hundred percent financing of the green space sector, a large share of funds goes to labour remuneration or social events. On the other hand, this situation shows insufficient funds even with one hundred percent financing. Which implies the following:

- non-compliance of organisational and economic support with the real needs of landscaping facilities;

- extremely low level of involvement of the private sector in the field of green space improvement, preferential financing from the state and local budgets.

Solutions to problems can be found in the following measures:

- organisation of independent expert supervisors for the quality of landscaping works under the city government;

- creation of the State Parks Agency of Ukraine, based on which expert commissions and groups will be created, and financial projects will be coordinated;

- attracting funds from sponsors and investors, stimulating public-private partnerships in the field of park improvement, trust agreements and easement;

- introduction of economic mechanisms to encourage organisations to improve parks, including: tax incentives, insurance protection, market assistance, and stimulating the investment attractiveness of parks;

- exclusion of the corruption component, keeping records of expenses and their publication based on the model of European countries and the United States.

Economic analysis of indicators of green space care provision has shown that there are "stable" areas - with constant high, medium or constant low provision, and there are areas that have moved from the status of high green space care provision to the status of low provision over the past five years.

Based on the identified problems, additional sources of extra-budgetary financing of parks and economic 
mechanisms for their stimulation are proposed. World experience shows that a socially oriented approach is becoming more and more relevant in the field of park management every year. Therefore, it is important for Ukraine not to miss this trend. In addition to the rich foreign experience in the field of park construction, the development of the principles of inclusive nature management, which can be widely implemented in the parks of Ukrainian cities, is relevant. Prospects for further study are the detailed development of mechanisms for implementing public-private enterprises in the field of park management, the creation of the state parks agency in Ukraine, and the development of features of its functioning.

\section{References}

[1] Krutsevych, T.Y., \& Pengelova, N.E. (2013). Foreign experience in organizing recreational activities for children in park complexes. Sportyvnyi Visnyk Prydniprovia, 2, 41-43.

[2] Kopievska, O.R. (1999). Socio-cultural aspects of the organization of parks in foreign countries (Doctoral thesis, Kyiv National University of Culture and Arts, Kyiv, Ukraine).

[3] Kovtun, V.D. (2005). Sociology of park construction as a direction of branch sociology. Culture and Modernity: Almanac, 2, 154-160.

[4] Bobukh, I.M. (2010). The proportions and perspectives of the formation of the national wealth of Ukraine. Kyiv: Institute of Economics and Forecasting of the National Academy of Sciences of Ukraine.

[5] Burkinskyi, B.V., \& Goryachuk, V.F. (2014). Capitalization of the economy of the regions of Ukraine. Odesa: IPREED NANU.

[6] Shevchenko, H.M., \& Petrushenko, M.M. (2008). Market natural and recreational potential of the territory. In Environmental management in the general management system: Materials of the eighth annual All-Ukrainian scientific conference (pp. 164-167). Sumy: Sumy State University.

[7] Balatsky, O.F., Petrushenko, M.M., \& Shevchenko, H.M. (2012). Conflict component of the system of socio-natural relations in the economic sphere of relations. Mechanism of Economic Regulation, 2, 140-153.

[8] NRPA National Recreation and Park Association. (2019). Parks \& Recreation. Retrieved from https://www.nrpa.org/parksrecreation-magazine/2019/november/nrpa-park-metrics-replaces-outdated-nrpa-areas-and-facilities-standards/.

[9] Dolesh, R.J. (2021). Top trends in Parks and Recreation in 2021. Parks \& Recreation. Retrieved from https://www.nrpa. org/parks-recreation-magazine/2021/january/top-trends-in-parks-and-recreation-2021/.

[10] DiGioia, C. (2021). Special events in the time of COVID-19. Parks \& Recreation. Retrieved from https://www.nrpa.org/ parks-recreation-magazine/2021/may/special-events-in-the-time-of-covid-192/.

[11] Lau, C. (2021). From plans to parks. Parks \& Recreation. Retrieved from https://www.nrpa.org/parks-recreationmagazine/2021/may/from-plans-to-parks/.

[12] Astell-Burt, T., Feng, X., Mavoa, S., Badland, H.M., \& Giles-Corti, B. (2014). Do low-income neighbourhoods have the least green space? A cross-sectional study of Australia's most populous cities. BMC Public Health, 14, article number 292.

[13] Jones, A., Hillsdon, M., \& Coombes, E. (2009). Greenspace access, use, and physical activity: Understanding the effects of area deprivation. Preventive Medicine, 49, 500-505.

[14] Leslie, E., Cerin, E., \& Kremer, P. (2010). Perceived neighborhood environment and park use as mediators of the effect of area socio-economic status on walking behaviors. Journal of Physical Activity and Health, 7, 802-810.

[15] Crompton, J.L. (2021). More public-private partnership models. Parks \& Recreation. Retrieved from https://www.nrpa. org/parks-recreation-magazine/2021/may/more-public-private-partnership-models/.

[16] Storonyanska, I., Patytska, K., Hrynchyshyn, I., \& Chemerys, V. (2020). Spatial disproportions in development of territorial community under conditions of administrative and financial decentralization. Agricultural and Resource Economics: International Scientific E-Journal, 6(4), 43-62. doi: 10.51599/are.2020.06.04.03.

[17] The economic impact of local parks. (2020). Retrieved from https://www.nrpa.org/publications-research/researchpapers/the-economic-impact-of-local-parks/.

[18] Reporting “Green Economy” for 2014. (2016). Retrieved from https://www.minregion.gov.ua/napryamki-diyalnosti/ zhkh/terretory/stan-sferi-zelenogo-gospodarstva-za-2014-rik/.

[19] Reporting “Green Economy” for 2015. (2016). Retrieved from https://www.minregion.gov.ua/press/news/stan-sferizelenogo-gospodarstva-za-2015-rik/.

[20] Reporting “Green Economy” for 2016. (2017). Retrieved from https://www.minregion.gov.ua/napryamki-diyalnosti/ zhkh/terretory/stan-sferi-zelenogo-gospodarstva-za-2016-rik/.

[21] Reporting “Green Economy” for 2017. (2018). Retrieved from https://www.minregion.gov.ua/napryamki-diyalnosti/ zhkh/terretory/stan-sferi-zelenogo-gospodarstva-za-2017-rik/.

[22] Reporting “Green Economy” for 2018. (2019). Retrieved from https://www.minregion.gov.ua/napryamki-diyalnosti/ zhkh/terretory/stan-sferi-zelenogo-gospodarstva-za-2018-rik/. 
[23] Reporting “Green Economy” for 2019. (2020). Retrieved from https://www.minregion.gov.ua/napryamki-diyalnosti/ zhkh/terretory/stan-sfery-zelenogo-gospodarstva-za-2019/.

[24] State building norms of Ukraine. Planning and development of territories. DBN B.2.2-12: 2019. (2019). Retrieved from https://dbn.co.ua/load/normativy/dbn/b_2_2_12/1-1-0-1802.

[25] Law of Ukraine No. 2807-IV “On improvement of settlements”. (2005, September). Retrieved from https://zakon.rada. gov.ua/laws/show/2807-15\#Text.

[26] How much is a green city? (2019). Retrieved from https://pragmatika.media/skolko-stoit-zelenyj-gorod/.

[27] Ministry of Development of Communities and Territories of Ukraine. (n.d.). Retrieved from https://www.minregion.gov.ua.

[28] Report of the Chernihiv Regional State Administration on the "Program of development and preservation of green areas of settlements of the Chernihiv region for 2013-2017”. (2013, June). Retrieved from https://chor.gov.ua/nashadiyalnist/novini/item/1372-pro-zatverdzhennia-prohramy-rozvytku-ta-zberezhennia-zelenykh-nas.

[29] Urban green areas: A quick guide to action. (2017). Retrieved from https://www.euro.who.int/ru/health-topics/ environment-and-health/urban-health/publications/2017/urban-green-spaces-a-brief-for-action-2017.

[30] Plastun, A., Yelnikova, Y., Shelyuk, A., Vorontsova, A., \& Artemenko, A. (2020). The role of public investment policy and responsible investment in financing sustainable development. Agricultural and Resource Economics: International Scientific E-Journal, 6(2), 108-125. doi: 10.51599/are.2020.06.02.07.

[31] Petrova, I.V. (2005). Leisure in foreign countries. Kyiv: Condor.

[32] What is a land trust? (n.d.). Retrieved from https://ua.nesrakonk.ru/land-trust/.

[33] Baldych, N., Hrynchuk, N., Khodko, N., Chorniy, L., \& Glibishchuk, J. (2020). Local economic development: Models, resources and financing tools. Canada: Federation of Canadian Municipalities.

[34] Tretiak, A., Tretiak, V., Sakal, O., Kovalenko, A., Tretiak, N., \& Shtogryn, H. (2020). The value added chain in the mechanism of public-private partnership for the development of the land use economy of rural territories. Agricultural and Resource Economics: International Scientific E-Journal, 6(3), 112-134. doi: 10.51599/are.2020.06.03.07.

[35] EUROPARC Federation. (n.d.). Retrieved from https://www.europarc.org.

[36] Petrushenko, M.M. (2020). Inclusive economics of experience - health recreation: From industrial to contemplative use of nature. Economic Innovations, 2(75), 82-92.

\title{
Аналіз організаційно-економічного забезпечення міських парків в Україні
}

\section{Наталія Валеріївна Вернігорова}

\author{
Інститут проблем ринку та економіко-екологічних досліджень НАН України \\ 65044, Французький бульвар, 29, м. Одеса, Україна
}

\begin{abstract}
Анотація. Вимоги сучасного суспільства до міських парків репрезентують їх як поліфункціональні території. Світові тенденції показують, що парки мають соціальну сутність та зорієнтовані на створення здорового та естетичного середовища. Натомість в Україні, парки розглядаються лише як ландшафтно-архітектурні комплекси. Тому їх фінансування відбувається за програмами містобудування і за рахунок бюджетних коштів. Залучення коштів організацій в сферу паркового благоустрою потребує більшої інтеграції парків в соціально-економічну систему. Водночас необхідна розробка механізмів економічного стимулювання організацій брати участь у благоустрої паркових територій. Метою статті $є$ економічний аналіз сучасного фінансування сфери зеленого господарства в Україні та розробка пропозицій додаткових джерел фінансового забезпечення парків. У даній науковій статті за допомогою аналітичного методу проведено облік фінансового стану зеленого господарства за регіонами України. Виділено типові проблеми сучасного фінансування, основні недоліки бюджетного фінансування і проблеми комерційних організацій в сфері озеленення міст. 3 використанням методу економіко-математичного моделювання (індексний метод), проведено аналіз змін показників забезпечення зеленими насадженнями та відповідно показників їх фінансового стану. Практичне значення статті полягає у розробці рекомендацій щодо додаткових шляхів фінансування паркового господарства на основі впровадження практики публічних приватних партнерств, трастових угод та сервітуту. Сформовано вимоги до юридичних осіб, що мають право на укладання подібних угод. Запропоновано економічний механізм стимулювання утворення публічних приватних партнерств та укладання угод в сфері благоустрою парків
\end{abstract}

Ключові слова: паркове господарство, озеленення міст, природний капітал, інфраструктурне забезпечення, благоустрій територій, громадський простір 